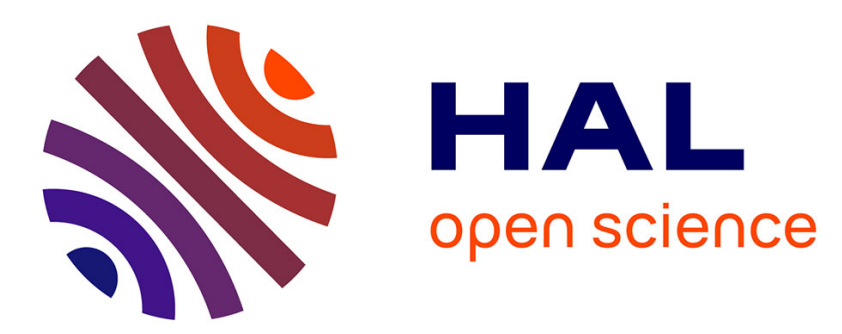

\title{
Contribution to the knowledge of the oribatid mite genus Pilobatella (Acari, Oribatida, Haplozetidae)
}

Sergey G. Ermilov, Josef Starý

\section{To cite this version:}

Sergey G. Ermilov, Josef Starý. Contribution to the knowledge of the oribatid mite genus Pilobatella (Acari, Oribatida, Haplozetidae). Acarologia, 2020, 60 (3), pp.545-556. 10.24349/acarologia/20204384 . hal-02888627

\section{HAL Id: hal-02888627 \\ https://hal.science/hal-02888627}

Submitted on 3 Jul 2020

HAL is a multi-disciplinary open access archive for the deposit and dissemination of scientific research documents, whether they are published or not. The documents may come from teaching and research institutions in France or abroad, or from public or private research centers.
L'archive ouverte pluridisciplinaire HAL, est destinée au dépôt et à la diffusion de documents scientifiques de niveau recherche, publiés ou non, émanant des établissements d'enseignement et de recherche français ou étrangers, des laboratoires publics ou privés. 


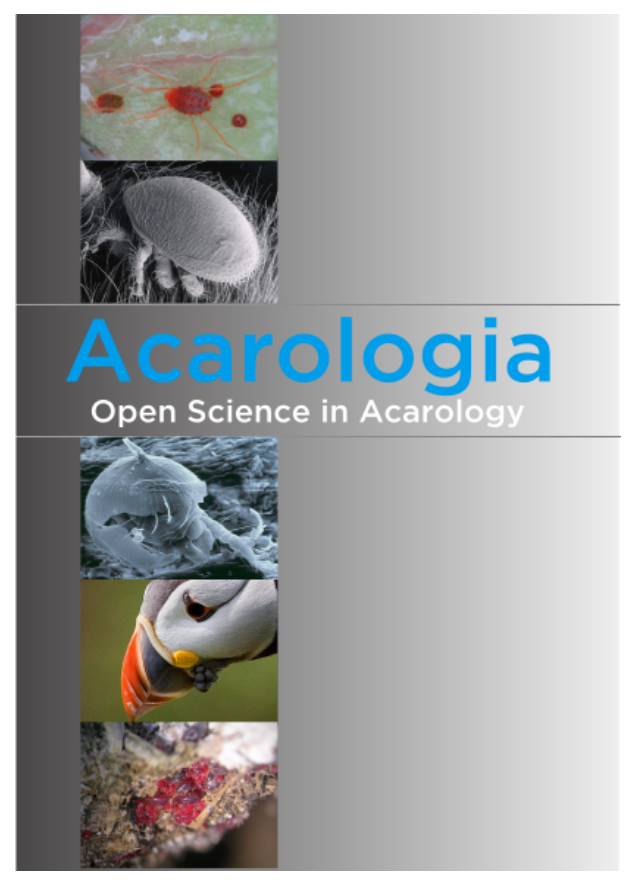

\section{Acarologia}

A quarterly journal of acarology, since 1959

Publishing on all aspects of the Acari

All information:

http://www1.montpellier.inra.fr/CBGP/acarologia/ acarologia-contact@supagro.fr

\section{OPEN ACCESS}

\section{Acarologia is proudly non-profit, with no page charges and free open access}

Please help us maintain this system by encouraging your institutes to subscribe to the print version of the journal and by sending us your high quality research on the Acari.

Subscriptions: Year 2020 (Volume 60): $450 €$ http://www1.montpellier.inra.fr/CBGP/acarologia/subscribe.php

Previous volumes (2010-2018): $250 €$ / year (4 issues)

Acarologia, CBGP, CS 30016, 34988 MONTFERRIER-sur-LEZ Cedex, France

ISSN 0044-586X (print), ISSN 2107-7207 (electronic)

The digitalization of Acarologia papers prior to 2000 was supported by Agropolis Fondation under the reference ID 1500-024 through the « Investissements d'avenir » programme

(Labex Agro: ANR-10-LABX-0001-01)
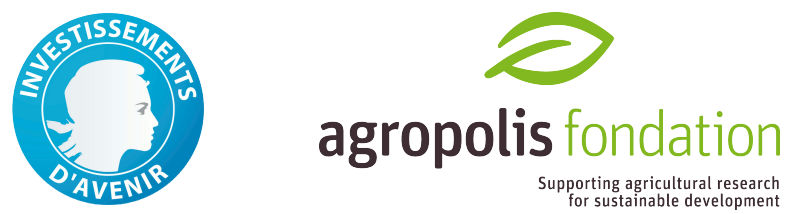

Acarologia is under free license and distributed under the terms of the

Creative Commons-BY-NC-ND which permits unrestricted non-commercial use, distribution, and reproduction in any medium, provided the original author and source are credited. 


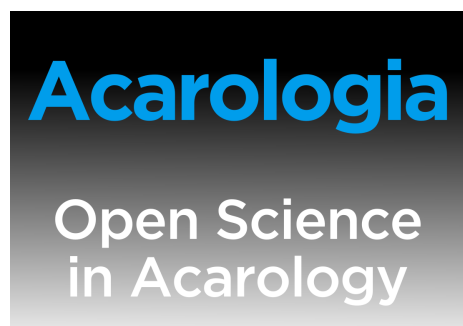

\section{Contribution to the knowledge of the oribatid mite genus Pilobatella (Acari, Oribatida, Haplozetidae)}

\author{
Sergey G. Ermilov ${ }^{a}$, Josef Starý ${ }^{b}$ \\ ${ }^{a}$ Institute of Environmental and Agricultural Biology (X-BIO), Tyumen State University, Tyumen, Russia. \\ ${ }^{b}$ Biology Centre v.v.i., Czech Academy of Sciences, Institute of Soil Biology, České Budějovice, Czech \\ Republic.
}

\section{Original research}

\section{ABSTRACT}

The genus Pilobatella (Oribatida, Haplozetidae) comprises 10 species, which are distributed in the Palaeotropical region; this includes two new species described herein on the basis of adult specimens sampled from forest leaf litter in Andasibe-Mantadia National Park of eastern Madagascar. Pilobatella mikoi n. sp. is similar to Pilobatella baloghi Mahunka, 2003 in having long interlamellar setae and adanal setae $a d_{1}$ and $a d_{2}$, but differs by having monodactylous legs (versus tridactylous) and a bothridial seta that is gradually expanded to a narrow head (versus setiform, without head). Pilobatella kovaci n. sp. is similar to P. mikoi n. sp. in having monodactylous legs, long interlamellar setae and adanal setae $a d_{1}$ and $a d_{2}$, but differs by the presence of lineolate notogaster and anogenital region (versus lineolate markings absent), long tutoria (versus tutoria of medium length), rounded trochanters distodorsally (versus pointed) and clearly distanced medial ends of apodemes 2 (versus nearly touching at midline). A revised generic diagnosis and an identification key to known species of Pilobatella are presented.

Keywords haplozetid mites; systematics; morphology; Madagascar; Afrotropical region

Zoobank http://zoobank.org/26B249D6-B764-4936-BD6B-2BD704DA5711

\section{Introduction}

The oribatid mite genus Pilobatella of the family Haplozetidae (Acari, Oribatida) was proposed by Balogh and Mahunka (1967) with Pilobatella punctulata Balogh and Mahunka, 1967 as type species. According to Subías (online version 2020), the genus currently comprises eight species, which are collectively distributed in the Palaeotropical region. Like Subías, we exclude three other species from the genus: P. lowmanae Ermilov, Winchester and Wassie, 2012; . maurensis Scull, 1985; P. pseudovermiseta Corpuz-Raros, 1979. Subías offered no justification, but these species possess only one pair of aggenital setae instead of the three pairs indicated in the original generic diagnosis. While Subías (2020) suggested recombinations of these three species, his website is not formally published, and their placement should be considered separately in the future.

We do not support the subgeneric division of Pilobatella proposed by Subías (2017), which was based on a single trait that is known to be variable within numerous oribatid mite groups. He recognized the subgenus Pilobatella (Tripilobatella) as including those species with tridactylous legs, contrasted with those having monodactylous legs in the nominate subgenus. In the larger context of the family Haplozetidae, several other genera include species with a different number of claws (e.g., Haplozetes Willmann, 1935; Protoribates Berlese, 1908; Trachyoribates Berlese, 1908).
Copyright

Ermilov S. G. and Starý J.

Distributed under

Creative Commons CC-BY 4.0 
Our main goal is to describe and illustrate two new species of Pilobatella that were discovered during taxonomic identification of oribatid mites from Andasibe-Mantadia National Park, Madagascar. A second goal is to summarize and update information about the genus. The main diagnostic characteristics of Pilobatella were summarized by Balogh and Mahunka (1967) and Balogh and Balogh $(1984,1992)$, and augmented by Ermilov et al. 2012, but many traits were not discussed in these works; we present a more complete treatment below. We also expand on the species identification key of Ermilov et al. (2012) to include all 10 species currently included in Pilobatella.

\section{Materials and methods}

\section{Material}

Substrate samples containing oribatid mites were collected in Andasibe-Mantadia National Park during long-term official cooperation between the Moravian Museum in Brno (Czech Republic) and Université d'Antananarivo (Madagascar) in 2010-2014. Mites were extracted into $75 \%$ ethanol using Winkler apparatus. See the Material examined section for detailed location data for each new species.

\section{Methods}

Specimens were mounted in lactic acid on temporary cavity slides for measurement and illustration. Body length was measured in lateral view, from the tip of the rostrum to the posterior edge of the notogaster. Notogastral width refers to the maximum width of the notogaster in dorsal view (behind pteromorphs). Lengths of body setae were measured in lateral aspect. All body measurements are presented in micrometers. Formulas for leg setation are given in parentheses according to the sequence trochanter-femur-genu-tibia-tarsus (famulus included). Formulas for leg solenidia are given in square brackets according to the sequence genu-tibia-tarsus.

Drawings were made with a camera lucida using a Leica transmission light microscope“Leica DM 2500".

Morphological terminology used in this paper follows that of F. Grandjean: see Travé and Vachon (1975) for references, Norton (1977) for leg setal nomenclature, and Norton and Behan-Pelletier (2009), for overview.

The following abbreviations are used: $l a m=$ lamella; slam $=$ sublamella; $A l=$ sublamellar porose area; $t u=$ tutorium; $p l r=$ prodorsal lateral ridge; $r o, l e, i n, b s, e x=$ rostral, lamellar, interlamellar, bothridial and exobothridial setae, respectively; $D=\operatorname{dorsophragma;~} P=$ pleurophragma; $c, l a, l m, l p, h, p=$ notogastral setae; $S a, S 1, S 2, S 3=$ notogastral sacculi; ia, im, $i p, i h$, ips = notogastral lyrifissures; gla = opisthonotal gland opening; $a, m, h=$ subcapitular setae; $v, l, d, c m, a c m, u l, s u l, v t, l t=$ palp setae; $\omega=$ palp and leg solenidion; $c h a, c h b=$ cheliceral setae; $T g$ = Trägårdh's organ; $P d I, P d I I=$ pedotecta I, II, respectively; $1 a, 1 b, 1 c$, $2 a, 3 a, 3 b, 3 c, 4 a, 4 b, 4 c=$ epimeral setae; dis = discidium; $c p=$ circumpedal carina; $g$, $a g$, an, $a d=$ genital, aggenital, anal and adanal setae, respectively; $i a d=$ adanal lyrifissure; Amar = marginal porose area; $p o=$ preanal organ; $T r, F e, G e, T i, T a=$ leg trochanter, femur, genu, tibia, tarsus, respectively; $p a=$ leg porose area; $\sigma, \varphi=$ leg solenidia; $\varepsilon=$ leg famulus; $v, e v, b v, l, d, f t$, tc, it, $p, u, a, s, p v, p l=$ leg setae.

\section{Systematics}

\section{Generic diagnosis of Pilobatella}

Adult - Sexual species with dimorphism absent. Body size: Small to medium (length 300-650). Integument: Color light brown to dark brown. Body surface smooth or partially 
with ornamentation (foveolate or lineolate). Prodorsum: Rostrum rounded. Lamella long, narrow, well separated, without cusp and tooth distally. Translamella absent. Prolamella absent or very weakly developed. Sublamella linear. Sublamellar porose area present. Tutorium strong, ridge-like. Rostral, lamellar, interlamellar and exobothridial setae well developed, setiform, barbed; ro inserted dorsolaterally on the rostrum, le on end of lamella or on prodorsal surface medial to lam, in in interbothridial region. Bothridial seta long, setiform or thickened, sometimes with slightly dilated mediodistal part (head), ciliate. Bothridium cup-shaped, with anterolateral scale. Dorsophragma elongate longitudinally. Notogaster: Anterior margin of notogaster convex medially. Pteromorph movable, large, curved ventrally. Octotaxic system with four pairs of sacculi. With 10 pairs of short, setiform notogastral setae. Dorsosejugal porose area present or not observed. Gnathosoma. Subcapitulum diarthric. Palp with setation

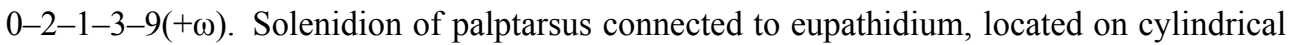
tubercle. Axillary saccule absent. Trägårdh's organ of chelicera elongate triangular to tapered. Lateral podosomal and epimeral regions: Pedotecta I and II represented by small lamina, $P d I I$ trapezoid to bifurcate in ventral aspect. Genal tooth and custodium absent. Discidium and circumpedal carina present. Humeral porose areas $A m, A h$ and $A l$ not observed. Typical epimeral setal formula 3-1-3-3. Anogenital region: Five or six pairs of genital, three pair of aggenital, two pairs of anal and three pairs of adanal setae. Adanal seta $a d_{1}$ posterior, $a d_{3}$ anterior or anterolateral to anal aperture. Adanal lyrifissure located close and lateral to anal plate. Marginal porose area usually present, narrowly band-like. Legs: All four legs similar, monodactylous (usually) or heterotridactylous. Porose area present dorsoparaxially on all femora and on trochanters III, IV. Porose area present proximoventrally on tarsi I-IV and distoventrally on tibiae I-IV.

Juvenile instars - Not known.

\section{Pilobatella mikoi n. sp.}

\section{Zoobank: CF211652-7361-41B6-85EB-3AA2938197B5}

\section{(Figures 1-3)}

Diagnosis - Body size 547-647 × 282-348. Rostral, lamellar and interlamellar setae long, setiform, barbed, ro shortest, in longest. Bothridial seta long, gradually thickening distally, beginning at mid-length, ciliate. Tutorium of medium length. All notogastral setae short, setiform, smooth. Epimeral, six pairs of genital and aggenital setae short, setiform, roughened. Medial end of each apodeme 2 close to midline. Anal and adanal setae setiform, erect, densely barbed, $a d_{1}$ and $a d_{2}$ long. All legs monodactylous. Trochanter IV pointed anterodorsally.

Description - Measurements - Body length 630 (holotype), 547-647 (seven paratypes); body width 348 (holotype), 282-348 (seven paratypes). Females larger than males: 630-647 315-348 versus $547-597 \times 282-298$.

Integument - Body light brown to dark brown. Surface of body and all legs microporose (visible under high magnification, $\times 1000$ ). Antiaxial side of femur II and paraxial side of femora III and IV striate.

Prodorsum (Figs 1a, 1c) - Rostrum rounded. Lamella about 1/2 length of prodorsum, strong. Prolamella absent. Sublamella about 1/3 length of lamella. Sublamellar porose area (16-20 × 10-12) oval, located ventral to sublamella. Tutorium of medium size, about $1 / 2$ length of lamella, ridge-like, distinctly not reaching rostral margin. Prodorsal lateral ridge distinct. Rostral (49-57), lamellar (65-77) and interlamellar (86-98) setae setiform, sparsely barbed; le located on lamellar end. Bothridial seta (94-98) long, narrow proximally, gradually dilating in distal half to narrow head, with short cilia bilaterally. Exobothridial seta (20-28) setiform, thin, slightly barbed. Sejugal porose area not observed.

Notogaster (Figs 1a, 1c) - Anterior notogastral margin slightly convex medially. Pteromorph triangular, rounded laterally, with slightly developed hinge. Ten pairs of notogastral setae (10-12) setiform, thin, smooth. Four pairs of sacculi present, Sa bipyriform, S1-S3 pyriform. Notogastral lyrifissure, opisthonotal gland opening, circumgastric scissure and circumgastric sigillar band distinct. 

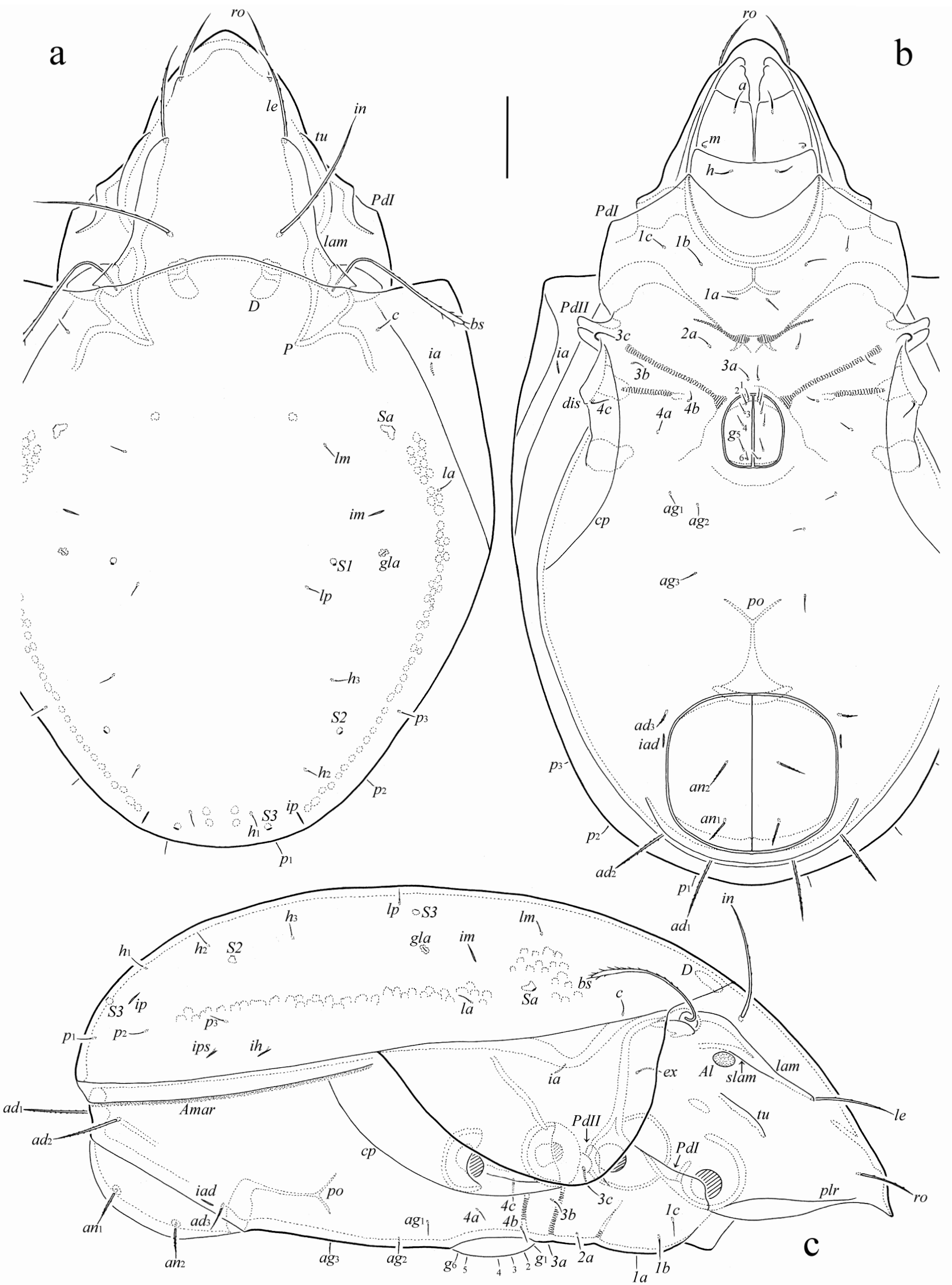

Figure 1 Pilobatella mikoi n. sp., adult: a - dorsal view (legs omitted); b - ventral view (legs omitted); c - lateral view (gnathosoma and legs omitted). Scale bar $50 \mu \mathrm{m}$. 
Gnathosoma (Figs 1b, 3c-e) - Subcapitulum size 131-139 × 77-86. Subcapitular setae $(a, 20-24 ; m, 10-12 ; h, 24-28)$ setiform, sparsely barbed, $m$ thinnest. Adoral seta (14-16) setiform, densely barbed. Palp (73-82) with typical formula. Postpalpal seta (4) spiniform, smooth. Chelicera (131-139) with two setiform, barbed setae (cha, 45-53; chb, 24-28).

Epimeral and lateral podosomal regions (Figs 1b, 1c) - Epimeral setal formula 3-1-3-3. All setae setiform, thin, roughened, $3 c$ (24-28) longer than $4 c$ (16-20), $1 b, 3 b(12-14)$ and others (10-12). Medial end of each apodeme 2 close to midline. Pedotectum II bifurcate apically in ventral view. Circumpedal carina long, directed to pedotectum II. Discidium triangular.

Anogenital region (Figs 1b, 1c) - Six pairs of genital (8-10) and three pairs of aggenital (8-12) setae setiform, thin, roughened. Two pairs of anal (22-24) and three pairs of adanal ( $a d_{1}$, $\left.a d_{2}, 41-49 ; a d_{3}, 14-16\right)$ setae setiform, erect, barbed. Adanal setae $a d_{1}$ and $a d_{2}$ inserted on arcuate ridge. Adanal lyrifissure distinct. Marginal porose area complete, narrowly band-like. Preanal organ goblet-like.

Legs (Figs 2a, 2b, 3a, 3b) - Monodactylous. Claw of all tarsi strong, slightly barbed on dorsal side, with tubercle ventrobasally. Claw of tarsi I and II thicker than that of tarsi III and IV. Tibiae I and II with tubercle proximoventrally. Femur II with broadly rounded ledge distoventrally. Trochanter IV pointed distodorsally. Dorsoparaxial porose area on all femora and on trochanters III, IV, and proximoventral porose area on all tarsi and distoventral porose area on all tibiae well visible. Formulas of leg setation and solenidia: I (1-5-3-4-20) [1-2-2], II (1-5-3-4-15) [1-1-2], III (2-3-1-3-15) [1-1-0], IV (1-2-2-3-12) [0-1-0]; homology of setae and solenidia indicated in Table 1 . Famulus of tarsus I short, erect, slightly dilated distally, inserted between solenidion $\omega_{2}$ and seta $f t^{\prime \prime}$. Solenidion $\omega_{1}$ on tarsi I, $\omega_{1}$ and $\omega_{2}$ on tarsus II and $\sigma$ on genu III bacilliform, other solenidia setiform. Seta $p l^{\prime}$ on tarsus I located dorsally on segment, posterior to seta $f t^{\prime \prime}$. Seta $l^{\prime \prime}$ on genu I inserted on tubercle.

Material examined - Holotype (female) and seven paratypes (three males and four females): Madagascar, Andasibe-Mantadia National Park, evergreen rain forest, $18^{\circ} 49^{\prime} 36^{\prime \prime} \mathrm{S}$, $48^{\circ} 26^{\prime} 52^{\prime \prime} \mathrm{E}, 550 \mathrm{~m}$ a.s.1., Winkler apparatus extraction of sifted leaf litter, 28.I.2014 (sample MAG-290 collected by R. Ravebolun and L. Rabotenoson).

Type deposition - The holotype is deposited in the collection of the Senckenberg Institute, Görlitz, Germany. Seven paratypes are deposited in the collection of the Tyumen State University Museum of Zoology, Tyumen, Russia. Specimens are preserved in ethanol with a drop of glycerol.

Etymology - The species name is dedicated to our friend and colleague, the well-known acarologist Prof. Dr. Ladislav Miko (Slovakia, Bratislava), for his extensive contributions to our knowledge of oribatid mites.

Remarks - In having long interlamellar setae and adanal setae $a d_{1}$ and $a d_{2}$, Pilobatella mikoi n. sp. is morphologically most similar to Pilobatella baloghi Mahunka, 2003 from Kenya. It differs from the latter by having monodactylous legs (versus tridactylous legs) and a bothridial seta that is gradually expanded to a narrow head (versus setiform, without head).

Table 1 Leg setation and solenidia of adult Pilobatella mikoi n. sp. and P. kovaci n. sp.

\begin{tabular}{|c|c|c|c|c|c|}
\hline Leg & $\operatorname{Tr}$ & $\mathrm{Fe}$ & Ge & $T i$ & $\mathrm{Ta}$ \\
\hline $\bar{I}$ & $v^{\prime}$ & $d,(l), b v^{\prime}, v^{\prime \prime}$ & $(l), v^{\prime}, \sigma$ & $(l),(v), \varphi_{1}, \varphi_{2}$ & $(f t),(t c),(i t),(p),(u),(a), s,(p v), v^{\prime},(p l), l ”, \varepsilon, \omega_{1}, \omega_{2}$ \\
\hline II & $v^{\prime}$ & $d,(l), b v^{\prime}, v^{\prime}$ & $(l), v^{\prime}, \sigma$ & $(l),(v), \varphi$ & (ft), (tc), (it), (p), (u), (a), s, (pv), $\omega_{1}, \omega_{2}$ \\
\hline III & $v^{\prime}, l^{\prime}$ & $d, l^{\prime}, e v^{\prime}$ & $l ', \sigma$ & $l ',(v), \varphi$ & $(f t),(t c),(i t),(p),(u),(a), s,(p v)$ \\
\hline IV & $v^{\prime}$ & $d, e v^{\prime}$ & $d, l$, & $l ',(v), \varphi$ & $f t ”,(t c),(p),(u),(a), s,(p v)$ \\
\hline
\end{tabular}

Note: Roman letters refer to normal setae, Greek letters to solenidia (except $\varepsilon$ = famulus). Single prime (') marks setae on anterior and double prime (") setae on posterior side of the given leg segment. Parentheses refer to a pair of setae. 


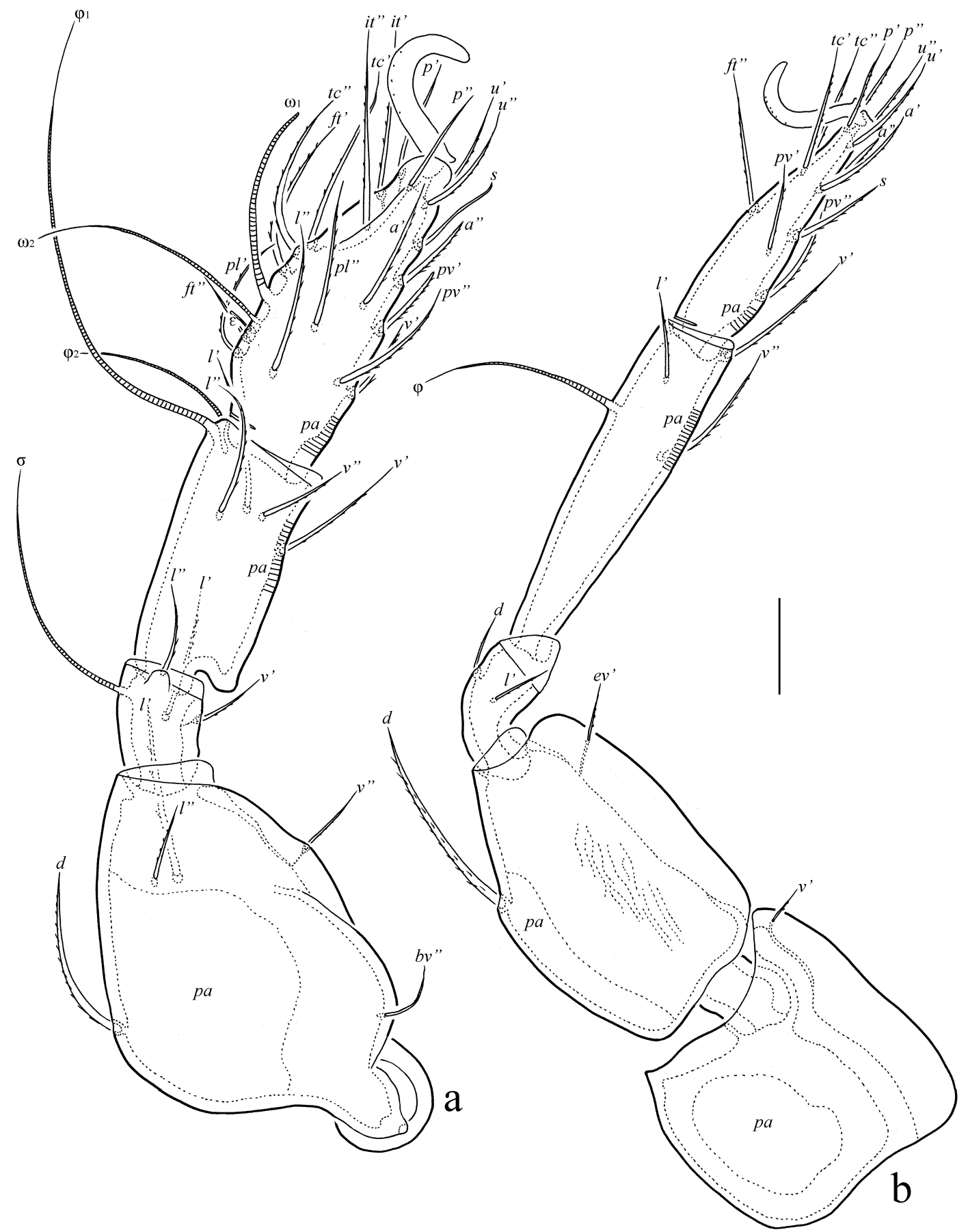

Figure 2 Pilobatella mikoi n. sp., adult: a - leg I, right, antiaxial view; b - leg IV, left, antiaxial view. Scale bar $20 \mu \mathrm{m}$.

Pilobatella kovaci n. sp.

Zoobank: A9C8AE64-9D65-4F32-98CE-704D77A4E4D0

(Figure 4)

Diagnosis - Body size 531-581 × 249-332. Rostral, lamellar and interlamellar setae long, setiform, barbed, ro shortest, in longest. Bothridial seta long, gradually thickening distally, beginning at mid-length, ciliate. Tutorium long. All notogastral setae short, setiform, smooth. 


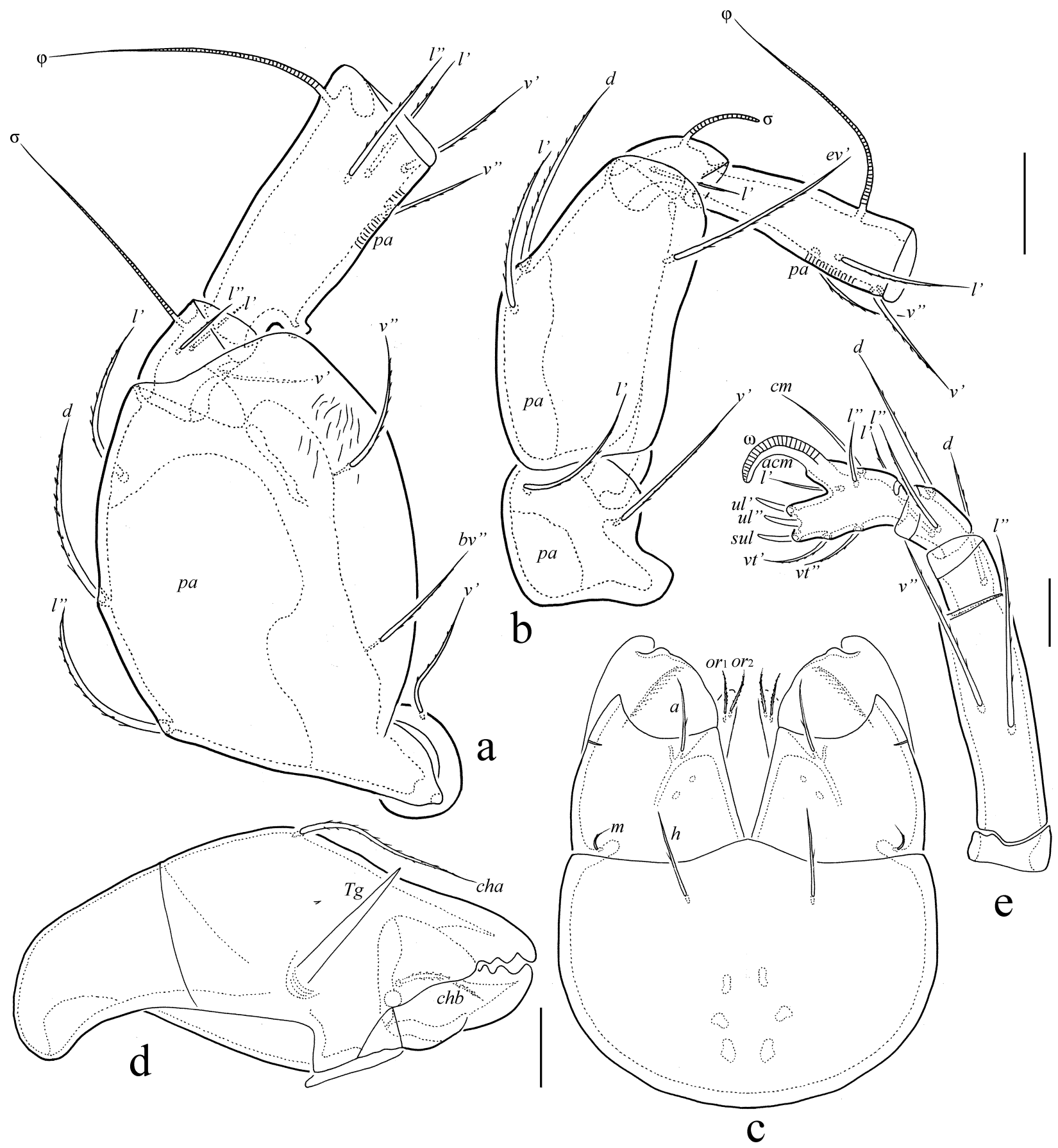

Figure 3 Pilobatella mikoi n. sp., adult: a - leg II, without tarsus, right, antiaxial view; b - leg III, without tarsus, left, antiaxial view; csubcapitulum, ventral view; d - chelicera, left, paraxial view; e - palp, left, antiaxial view. Scale bar $20 \mu \mathrm{m}$ (a-d), scale bar $10 \mu \mathrm{m}$ (e).

Epimeral, six pairs of genital and aggenital setae short, setiform, roughened. Medial end of apodeme 2 well removed from midline. Anal and adanal setae setiform, erect, densely barbed, $a d_{1}$ and $a d_{2}$ long. All legs monodactylous. Trochanter IV rounded anterodorsally.

Description - Measurements - Body length 564 (holotype), 531-581 (three paratypes); body width 282 (holotype), 249-332 (three paratypes). Females larger than males: 564-581 $\times$ 
282-332 versus 531-547 × 249-265.

Integument - Body light brown. Surface of body and all legs microporose (visible under high magnification, $\times 1000$ ). Notogaster, anogenital region and anal plate lineolate, with short depressed, distinct lines. Epimeral region and genital plate microlineolate. Lateral part of body microgranulate. Antiaxial side of femora I, II and paraxial side of femora III and IV striate.

Prodorsum (Figs 4a, 4c) - Rostrum rounded. Lamella about 1/2 length of prodorsum, strong. Prolamella absent. Sublamella about 1/2 length of lamella. Sublamellar porose area (14-16 $\times$ 8-10) oval, located ventral to sublamella. Tutorium long, similar in length to lamella, ridgelike, almost reaching rostral margin. Prodorsal lateral ridge distinct. Rostral (53-61), lamellar (61-69) and interlamellar (73-82) setae setiform, slightly barbed; le located on lamellar end. Bothridial seta (86-90) gradually thickening distally, beginning at mid-length, shortly ciliate bilaterally. Exobothridial seta (28-41) setiform, thin, slightly barbed. Sejugal porose area not observed.

Notogaster (Figs 4a, 4c) - Anterior notogastral margin slightly convex medially. Pteromorph triangular, rounded laterally, with slightly developed hinge. Ten pairs of notogastral setae (6-8) setiform, thin, smooth. Four pairs of sacculi pyriform. Notogastral lyrifissure, opisthonotal gland opening, circumgastric scissure and circumgastric sigillar band distinct.

Gnathosoma - Generally, similar to those of Pilobatella mikoi n. sp. Subcapitulum size 131-135 × 77-86. Subcapitular setae $(a, 16-20 ; m, 8-10 ; h, 20-24)$ setiform, roughened, $m$ thinnest. Adoral seta (12) setiform, densely barbed. Palp (73-82) with typical formula. Postpalpal seta (4) spiniform, smooth. Chelicera (131-135) with two setiform, barbed setae (cha, 45-49; chb, 24-28).

Epimeral and lateral podosomal regions (Figs 4b, 4c) - Epimeral setal formula 3-1-3-3. All setae setiform, thin, roughened, $3 c$ (28-41) longer than $4 c(16-20)$ and others $(10-14)$. Medial end of apodeme 2 well removed from midline. Pedotectum II bifurcate apically in ventral view. Circumpedal carina long, directed to pedotectum II. Discidium triangular.

Anogenital region (Figs 4b, 4c) - Six pairs of genital (6-8) and three pairs of aggenital (8-12) setae setiform, thin, roughened. Two pairs of anal (20-24) and three pairs of adanal $\left(a d_{1}\right.$, $\left.a d_{2}, 41-49 ; a d_{3}, 12-16\right)$ setae setiform, erect, barbed. Adanal setae $a d_{1}$ inserted on arcuate ridge, $a d_{2}$ near this ridge. Adanal lyrifissure distinct. Marginal porose area complete, narrowly band-like. Preanal organ goblet-like.

Legs - Generally, similar to those of Pilobatella mikoi n. sp. Monodactylous. Claw of all tarsi strong, slightly barbed on dorsal side, with tubercle ventrobasally. Claw of tarsi I and II thicker than that of tarsi III and IV. Tibiae I and II with tubercle ventrobasally. Femur II with broadly rounded ledge distoventrally. Trochanter IV rounded distodorsally. Dorsoparaxial porose area on all femora and on trochanters III, IV, and proximoventral porose area on all tarsi and distoventral porose area on all tibiae well visible. Formulas of leg setation and solenidia: I (1-5-3-4-20) [1-2-2], II (1-5-3-4-15) [1-1-2], III (2-3-1-3-15) [1-1-0], IV (1-2-2-3-12) [0-1-0]; homology of setae and solenidia indicated in Table 1. Famulus of tarsus I short, erect, slightly dilated distally, inserted between solenidion $\omega_{2}$ and seta $f t^{\prime \prime}$. Solenidion $\omega_{1}$ on tarsus I, $\omega_{1}$ and $\omega_{2}$ on tarsus II and $\sigma$ on genu III bacilliform, other solenidia setiform. Seta $p l^{\prime}$ on tarsus I located dorsally on segment, posterior to seta $f^{\prime \prime}$. Seta $l^{\prime \prime}$ on genu I inserted on tubercle.

Material examined - Holotype (female) and three paratypes (two males and one female): Madagascar, Andasibe-Mantadia National Park, evergreen rain forest, $18^{\circ} 49^{\prime} 36^{\prime \prime} \mathrm{S}, 48^{\circ} 26^{\prime} 52^{\prime \prime} \mathrm{E}$, $550 \mathrm{~m}$ a.s.1., Winkler apparatus extraction of sifted leaf litter, 28.I.2014 (sample MAG-290 collected by R. Ravebolun and L. Rabotenoson).

Type deposition - The holotype is deposited in the collection of the Senckenberg Institute, Görlitz, Germany. Three paratypes are deposited in the collection of the Tyumen State University Museum of Zoology, Tyumen, Russia. Specimens are preserved in ethanol with a drop of glycerol.

Etymology - The species name is dedicated to our friend and colleague, the well-known soil ecologist Prof. Dr. Lubomír Kováč (Slovakia, Košice), for his extensive contribution 


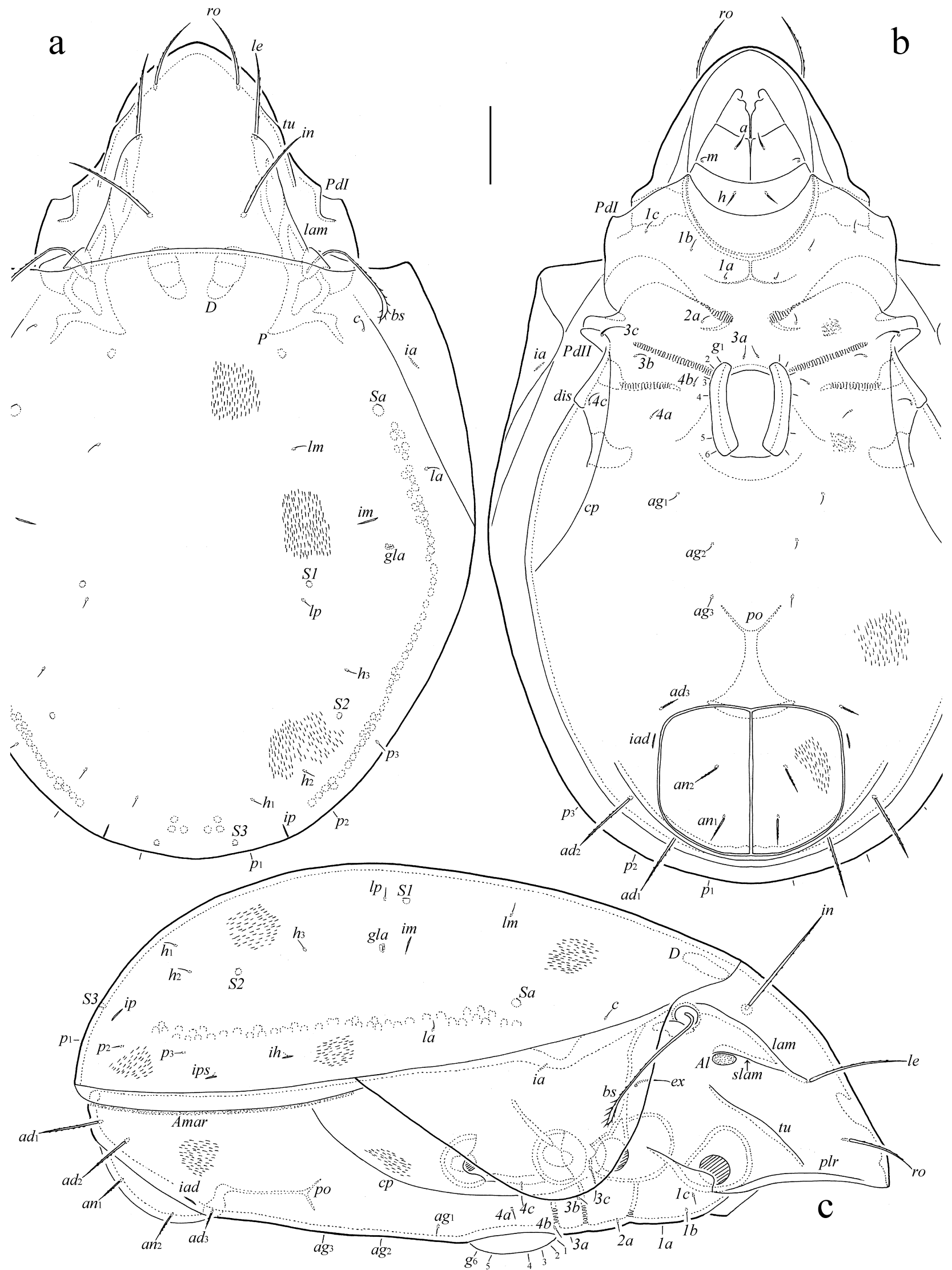

Figure 4 Pilobatella kovaci n. sp., adult: a - dorsal view (legs omitted); b - ventral view (legs omitted); c - lateral view (gnathosoma and legs omitted). Scale bar $50 \mu \mathrm{m}$. 
to our knowledge of taxonomy and ecology of soil and troglophilous species of springtails (Collembola) and other groups of cave mesofauna.

Remarks - In having monodactylous legs, long interlamellar setae and adanal setae $a d_{1}$ and $a d_{2}$, Pilobatella kovaci n. sp. is morphologically most similar to P. mikoi n. sp. from Madagascar, but differs from the latter by the presence of its lineolate notogaster and anogenital region (versus lineolate markings absent), long tutoria (versus tutoria of medium length), rounded trochanters anterodorsally (versus pointed) and clearly distanced medial ends of apodemes 2 (versus nearly touching at midline).

\section{Key to known species of Pilobatella}

1. Interlamellar setae long (not shorter than lamellae)

— Interlamellar setae of medium length or short (clearly shorter than lamellae)

2. Adanal setae $a d_{1}$ and $a d_{2}$ short (distinctly shorter than width of one anal plate); notogastral sacculi $\mathrm{Sa}$ distinctly elongate; body size: $531-614 \times 249-298$

....................... Pilobatella dhatiensis Ermilov, 2019. Distribution: Ethiopia.

- Adanal setae $a d_{1}$ and $a d_{2}$ long (not shorter than width of one anal plate); notogastral sacculi

$\mathrm{Sa}$ with form of single or double drop.

3. Leg tarsi heterotridactylous; body size: $520-556 \times 277-297$

- Leg tarsi monodactylous

Pilobatella baloghi Mahunka, 2003. Distribution: Kenya.

4. Notogaster and anogenital region lineolate; tutoria long (similar to length of lamellae), leg trochanters IV rounded anterodorsally; body size: $531-581 \times 249-332$

Pilobatella kovaci n. sp. Distribution: Madagascar.

- Notogaster and anogenital region not lineolate; tutoria of medium size (clearly shorter than lamellae), leg trochanters IV pointed anterodorsally; body size: $547-647 \times 282-348$

. Pilobatella mikoi n. sp. Distribution: Madagascar.

5. Lamellar setae inserted on prodorsal surface between ends of lamellae and removed from

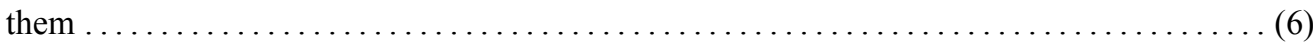

— Lamellar setae inserted on ends of lamellae or on prodorsal surface very close to them ..

6. Notogaster and anogenital region distinctly foveolate; body size: $348-407 \times 188-212 \ldots \ldots$ ..............Pilobatella schauenbergi Mahunka, 1977(a). Distribution: Oriental region. — Notogaster and anogenital region not distinctly foveolate; body size: 432-472 × 236-240 . ............. Pilobatella berlesei Bhattacharya and Banerjee, 1980. Distribution: India.

7. One or two transverse carinae present close to ends of lamellae; ends of sejugal apodemes fused medially, located anterior to genital aperture; body size: $297-332 \times 123-157 \ldots \ldots \ldots$. ................... Pilobatella xena Mahunka, 1977(b). Distribution: Ethiopian region. — Transverse prodorsal carinae absent; ends of sejugal apodemes separated medially, directed to genital aperture

8. Five pairs of genital setae; epimere 3 with one pair of semi-oval ridges; median epimeral region broad, clearly bordered; body size: $295-373 \times 121-183$

.Pilobatella monstruosa Mahunka, 1986. Distribution: Kenya.

- Six pairs of genital setae; epimere 3 without semi-oval ridges; median epimeral region not

bordered...

9. Notogaster and anogenital region foveolate; lamellar and interlamellar setae of medium length (longer than diameter of bothridia); body size: 382-407 × 190-200 
.... Pilobatella punctulata Balogh and Mahunka, 1967. Distribution: Ethiopian region, India. - Notogaster and anogenital region not foveolate; lamellar and interlamellar setae short (not longer than diameter of bothridia); body size: $330 \times 198$

Pilobatella brevipila Mahunka, 2011. Distribution: Madagascar.

\section{Acknowledgements}

We thank R. Ravebolun and L. Rabotenoson who collected soil and litter samples in Madagascar; and the Moravian Museum in Brno, Czech Republic, which kindly provided material for our study. Also, we would like to thank Dr. Lala Harivelo Ravaomanarivo Raveloson (University of Antananarivo, Faculty of Sciences, Department of Entomology), Dr. Mamy A. Rakotoarijaona (Directeur des Opérations, Madagascar National Parks, Antananarivo) and Dr. Dimby Raharinjanahary (Chargé des Bases de données de suivibiodiversité et recherche, Madagascar National Parks, Antananarivo) for supporting joint Czech-Madagascan research project (20092014); and Prof. Dr. Roy A. Norton (State University of New York, College of Environmental Science and Forestry, Syracuse, New York, USA), Dr. Julia Baumann (University of Graz, Graz, Austria) and one anonymous reviewer for valuable comments. Samples collected in Madagascar were based on collection permit no. 314/13/MEF/SG/DGF/DCB.SAP/SCB by the Moravian Museum in Brno, Czech Republic; sample exportation to Czech Republic was based on permit no. $028 \mathrm{~N}-\mathrm{EA} 02 / \mathrm{MG} 14$.

\section{References}

Balogh J., Balogh P. 1984. A review of the Oribatuloidea Thor, 1929 (Acari: Oribatei). Acta Zool. Hung., 30(3-4): 257-313.

Balogh J., Balogh P. 1992. The oribatid mite genera of the World. Vol. 1. Budapest, Hung. Nat. Mus. Press, 263 p.

Balogh J., Mahunka S. 1967. The scientific results of the Hungarian soil zoological expedition to the Brazzaville-Congo. 30. The oribatid mites (Acari) of Brazzaville-Congo, II. Opusc. Zool. Budapest, 7(1): 35-43.

Berlese A. 1908. Elenco di generi e specie nuove di Acari. Redia, 5: 1-15.

Bhattacharya T., Banerjee R. 1980. Some cryptostigmatid mites (Acari: Oribatei) from Birbhum district, West Bengal, India. Ind. J. Acarol., 4(1): 19-24.

Corpuz-Raros L.A. 1979. Philippine Oribatei (Acarina). I. Preliminary list of species and descriptions of forty new species. Philip. Agr., 62(1): 1-82.

Ermilov S.G. 2019. Two new species of Oripodoidea (Acari, Oribatida) from Ethiopia. Zool. Zh., 98(9): 1037-1047. doi:10.1134/S0044513419090046

Ermilov S.G., Winchester N.N., Lowman M.M., Wassie A. 2012. Two new species of oribatid mites (Acari: Oribatida) from Ethiopia, including a key to species of Pilobatella. Syst. Appl. Acarol., 17(3): 301-317. doi:10.11158/saa.17.3.9

Mahunka S. 1977a. Neue und interessante Milben aus dem Genfer Museum XX. Contribution to the oribatid fauna of S.E. Asia (Acari, Oribatida). Rev. suisse Zool., 84(1): 247-274. doi:10.5962/bhl.part. 91385

Mahunka S. 1977b. Neue und interessante Milben aus dem Genfer Museum XXXI. A remarkable sample of archaic soil mites from Kenya (Acari: Oribatida). Rev. suisse Zool., 84(2): 463-479. doi:10.5962/bhl.part.91400

Mahunka S. 1986. Studies on the oribatid fauna of Kenya (Acari: Oribatida) II. Folia Ent. Hung., 47(1-2): 77-102.

Mahunka S. 2003. Baloghoizetes gen n. and two new species from Kenya (Acari: Oribatida). Acta Zool. Acad. Sci. Hung., 49(1): 17-23.

Mahunka S. 2011. New and little known oribatid mites from Madagascar (Acari: Oribatida), II. Acta Zool. Acad. Sci. Hung., 57(1): 1-21.

Norton R.A. 1977. A review of F. Grandjean's system of leg chaetotaxy in the Oribatei (Acari) and its application to the family Damaeidae. In: Dindal D.L. (Ed.). Biology of oribatid mites. Syracuse: SUNY College of Environmental Science and Forestry. pp. 33-61.

Norton R.A., Behan-Pelletier V.M. 2009. Oribatida. Chapter 15. In: Krantz G.W., Walter D.E. (Eds.). A Manual of Acarology. Lubbock: Texas Tech University Press. pp. 430-564.

Scull I. 1985. Acaros oribátidos de los suelos pecuarios cubanos. IV. Parte. Rev. Cub. Cie. Vet., 16(1): 73-82.

Subías L.S. 2017. Listado sistemático, sinonímico y biogeográfico de los ácaros oribátidos (Acariformes: Oribatida) del mundo (excepto fósiles) (12a actualización). Online version accessed in February 2017, 598 pp. 
Subías L.S. 2020. Listado sistemático, sinonímico y biogeográfico de los ácaros oribátidos (Acariformes: Oribatida) del mundo (excepto fósiles) ( $15^{\mathrm{a}}$ actualización). Online version accessed in January 2020 , 527 pp.; http://bba.bioucm.es/cont/docs/RO_1.pdf

Travé J., Vachon M. 1975. François Grandjean. 1882-1975 (Notice biographique et bibliographique). Acarologia, 17(1): 1-19.

Willmann C. 1935. IV. Die Milbenfauna. 1. Oribatei. Zool. Jahr., Syst., Ökol. und Geogr. Tiere, 66(5): 331-355. 